\title{
LINking microRNAs, kidney development, and Wilms tumors
}

\author{
Peter Hohenstein ${ }^{1,2,3}$ and Nicholas D. Hastie ${ }^{2}$ \\ ${ }^{1}$ The Roslin Institute, University of Edinburgh, Midlothian EH23 4RB, United Kingdom; ${ }^{2}$ MRC Human Genetics Unit, MRC \\ Institute of Genetics and Molecular Medicine, University of Edinburgh, Western General Hospital, Edinburgh EH4 2XU, \\ United Kingdom
}

In this issue of Genes \& Development, Urbach and colleagues (pp. 971-982) provide compelling data suggesting a role for LIN28 in the pathogenesis of a significant percentage of Wilms tumors. These data extend our insights in the genetics underlying Wilms tumor development and emphasize the importance of stemness and microRNAmediated processes in the origins of these tumors.

Wilms tumors are pediatric cancers affecting one in 10,000 children. They are the result of normal kidney development going awry, possibly around the mesenchymal-to-epithelial transition (MET) stage at the onset of nephrogenesis. Histological and transcriptomic analyses of Wilms tumors have shown them to be a heterogeneous group of tumors that could originate from different developmental stages (Gadd et al. 2012). Mutations in different genes have been implicated as the driving force of these tumors, including the loss of WT1 and WTX and the activation of IGF2 and CTNNB1 (the gene encoding $\beta$-catenin). Of these, WT1 and CTNNB1 have been functionally linked to early kidney development and regulation of the progenitor cells undergoing the MET (Essafi et al. 2011; Park et al. 2012). The functional rationale for perturbations in WTX and IGF2 is less clear, although tumor analyses have clearly shown involvement at some stage of the tumorigenic process.

Urbach et al. (2014) now add the LIN28 genes to this group of Wilms tumor genes. Using doxycycline-inducible mouse models for overexpression of Lin28a and $L I N 28 B$, the investigators showed that activation of either gene results in the formation of Wilms tumors through either leaky expression of Lin28a in a Vasa-Credriven system or the directed expression of $L I N 28 B$ in the renal Wt1 lineage. The primary phenotype in the kidneys of these animals was a prolonged proliferation of the Six $2^{+}$ nephron progenitor cells that form the cap mesenchyme (Kobayashi et al. 2008). In wild-type animals, these cells undergo a final, synchronized differentiation a few days

[Keywords: kidney development; Wilms tumor; Lin28]

${ }^{3}$ Corresponding author

E-mail peter.hohenstein@roslin.ed.ac.uk

Article is online at http://www.genesdev.org/cgi/doi/10.1101/gad.242735.114. after birth. In mutant mice, they remained present as long as LIN28 expression was induced; it took several weeks after LIN28 withdrawal for the cells to finally undergo terminal differentiation. Unexpectedly-but consistent with this observation-the mutant cells were even able to epithelialize and form glomeruli in the presence of LIN28 overexpression. Therefore, a disturbance in the balance between proliferation and differentiation of these cells-rather than a differentiation block-seems to be the cause of these tumors.

The origin of the tumors in these models is not completely clear. Activation of a Wt1-Cre allele from as early as the onset of intermediate mesoderm formation-and therefore in the earliest precursor of the complete metanephric kidney-did drive tumorigenesis. However, restricted activation in the nephron progenitors (via Six2driven Cre), the stromal cells (Foxd1-Cre), or collecting duct (Cdh16-Cre) did not. We can thus conclude that either the transgenes need to be induced at a very early stage of kidney development or activation in multiple lineages is required. It is difficult to conclusively prove one or the other option using the current models

Wilms tumor cancer stem cells (CSCs) have recently been identified as $\mathrm{NCAM}^{+}{ }^{+} \mathrm{ALDH}^{+}$cells (Pode-Shakked et al. 2013). The clinical relevance of the LIN28 mouse models is underscored by the observation of increased LIN28B (but not LIN28A) expression in 18 of 105 Wilms tumor samples and CSCs. LIN28B expression was localized to the blastemal component, and a strong correlation was found between LIN28B expression, tumor relapse, and mortality. Although both LIN28A and LIN28B could induce tumor formation in mouse models, only LIN28B activation was observed in patient samples. This surprising observation could be explained through an unknown mechanism that drives the specific activation of the LIN28B locus.

Both LIN28 paralogs are known to have important and evolutionarily conserved roles in stemness (Shyh-Chang

(c) 2014 Hohenstein and Hastie This article is distributed exclusively by Cold Spring Harbor Laboratory Press for the first six months after the fullissue publication date (see http://genesdev.cshlp.org/site/misc/terms.xhtml). After six months, it is available under a Creative Commons License (Attribution-NonCommercial 4.0 International), as described at http:// creativecommons.org/licenses/by-nc/4.0/. 
and Daley 2013). Lin28a is highly expressed in mouse embryonic stem cells and, together with Oct4, Sox2, and Nanog, can reprogram somatic cells into induced pluripotent stem cells (iPSCs). Both Lin28a and Lin28b function through two different mechanisms: They can bind a wide variety of mRNAs to regulate their translation and can recruit terminal uridylyl transferases to inhibit the maturation of let-7 microRNAs (miRNAs). Uridylated prelet-7 cannot be processed by DICER into a mature miRNA and is therefore broken down by a nuclease. Via either route, LIN28 is directly involved in known metabolic and oncogenic pathways. To elucidate the mechanism by which LIN28 induces Wilms tumors, Urbach et al. (2014) crossed their tumor-prone mice with a model that expresses a LIN28-independent form of let-7 and found a complete rescue of the phenotype. Consistently, a dramatic increase in the expression of known let-7 targets was found in LIN28-induced tumors. Although this does not exclude a role for the mRNA-binding activity of LIN28, it is clear that let-7 suppression is essential for Wilms tumorigenesis in these models.

This study adds to an increasing amount of data implicating miRNAs in Wilms tumor development. In rare cases, translocation-mediated activation of LIN28B has been observed in Wilms tumors (Viswanathan et al. 2009), as has loss of DICER1 (Wu et al. 2013). Perlman syndrome, which is characterized by fetal overgrowth and a predisposition to Wilms tumors, is caused by loss of the gene encoding DIS $3 L 2$, the $3^{\prime}-5^{\prime}$ exonuclease that degrades prelet-7 after LIN28-mediated uridylation (Chang et al. 2013). Disruptions in miRNA expression and processing could be an important player in Wilms tumorigenesis, and on-going Wilms tumor genome sequencing projects will hopefully shed more light on this.

If the disruption of miRNA pathways can lead to the formation of Wilms tumors, which are thought to be the direct result of disturbed embryonic kidney development, one would expect an essential role for miRNAs in normal kidney development, in particular in the processes impaired in Wilms tumor formation. Indeed, conditional loss of Dicer in different renal lineages and in different developmental stages results in severe phenotypes (Nagalakshmi et al. 2011; Chu et al. 2014). A careful analysis of changes in miRNA expression patterns in Wilms tumor samples and comparison with the normal cell type-specific expression pattern of miRNAs in the developing kidney may identify new players, pathways, and therapeutic targets.

The roles of LIN28 in stemness and oncogenesis (ShyhChang and Daley 2013) raise the possibility of a functional role for Lin28 in Wilms tumor CSCs. As mentioned before, these cells are characterized by NCAM1 expression and ALDH1 activity. When these CSCs were first identified, it was noted that in normal kidney development, these two markers are not found in the same cell types, and it was suggested that NCAM1 acts as a marker for the developmental stage of origin, while ALDH1 activity was linked to the oncogenic characteristics of the cells (Pode-Shakked et al. 2013). Somehow, these two markers need to become expressed in the same cell.
Is it possible that LIN28 plays an active role in this? Urbach et al. (2014) show that the NCAM1 ${ }^{+}$ALDH1 $^{+}$ population expresses high levels of LIN28B. In breast cancer CSCs, the LIN28/let-7 pathway has been suggested to have a stimulating effect on the maintenance $\mathrm{ALDH}^{+}$cells (Yang et al. 2010). Another recent study demonstrated that premature termination of in vivo iPSC reprogramming, a process in which Lin28a can function as well, results in tumors resembling Wilms tumors (Ohnishi et al. 2014). These tumors could form secondary tumors through transplantation even after the induction of the reprogramming factors was lost. This could suggest that some CSC phenotype had been induced, although NCAM1 and ALDH1 were not analyzed. It would be interesting to see whether activation of LIN28 in the mice generated by Urbach et al. (2014) would directly result in the appearance of $\mathrm{NCAM1}^{+} \mathrm{ALDH}^{+}{ }^{+}$Wilms tumor CSCs and whether passaging of these tumors in immunocompromised mice is also possible in the absence of LIN28 induction, as is the case for the iPSC factor-induced tumors.

The identification of a role for LIN28 in driving Wilms tumor will likely affect many different aspects of Wilms tumor biology and normal kidney development and emphasizes the importance of studying these two sides of the same coin in a combined manner.

\section{Acknowledgments}

The Roslin Institute receives Institute Strategic Program Grant funding from the Biotechnology and Biological Sciences Research Council (BBSRC).

\section{References}

Chang HM, Triboulet R, Thornton JE, Gregory RI. 2013. A role for the Perlman syndrome exonuclease Dis312 in the Lin28let-7 pathway. Nature 497: 244-248.

Chu JY, Sims-Lucas S, Bushnell DS, Bodnar AJ, Kreidberg JA, Ho J. 2014. Dicer function is required in the metanephric mesenchyme for early kidney development. Am I Physiol Renal Physiol 306: F764-F772.

Essafi A, Webb A, Berry RL, Slight J, Burn SF, Spraggon L, Velecela V, Martinez-Estrada OM, Wiltshire JH, Roberts SG, et al. 2011. A Wt1-controlled chromatin switching mechanism underpins tissue-specific Wnt4 activation and repression. Dev Cell 21: 559-574.

Gadd S, Huff V, Huang CC, Ruteshouser EC, Dome JS, Grundy $\mathrm{PE}$, Breslow N, Jennings L, Green DM, Beckwith JB, et al. 2012. Clinically relevant subsets identified by gene expression patterns support a revised ontogenic model of Wilms tumor: a children's oncology group study. Neoplasia 14: 742-756.

Kobayashi A, Valerius MT, Mugford JW, Carroll TJ, Self M, Oliver G, McMahon AP. 2008. Six2 defines and regulates a multipotent self-renewing nephron progenitor population throughout mammalian kidney development. Cell Stem Cell 3: $169-181$.

Nagalakshmi VK, Ren Q, Pugh MM, Valerius MT, McMahon AP, Yu J. 2011. Dicer regulates the development of nephrogenic and ureteric compartments in the mammalian kidney. Kidney Int 79: 317-330.

Ohnishi K, Semi K, Yamamoto T, Shimizu M, Tanaka A, Mitsunaga K, Okita K, Osafune K, Arioka Y, Maeda T, 
et al. 2014. Premature termination of reprogramming in vivo leads to cancer development through altered epigenetic regulation. Cell 156: 663-677.

Park JS, Ma W, O'Brien LL, Chung E, Guo JJ, Cheng JG, Valerius MT, McMahon JA, Wong WH, McMahon AP. 2012. Six2 and Wnt regulate self-renewal and commitment of nephron progenitors through shared gene regulatory networks. Dev Cell 23: 637-651.

Pode-Shakked N, Shukrun R, Mark-Danieli M, Tsvetkov P, Bahar S, Pri-Chen S, Goldstein RS, Rom-Gross E, Mor Y, Fridman E, et al. 2013. The isolation and characterization of renal cancer initiating cells from human Wilms' tumour xenografts unveils new therapeutic targets. EMBO Mol Med 5: $18-37$.

Shyh-Chang N, Daley GQ. 2013. Lin28: primal regulator of growth and metabolism in stem cells. Cell Stem Cell 12: 395-406.

Urbach A, Yermalovich A, Zhang J, Spina CS, Zhu H, PerezAtayade AR, Shukrun R, Charlton J, Sebire N, Mifsud W, et al. 2014. Lin28 sustains early renal progenitors and induces Wilms tumor. Genes Dev (this issue). doi: 10.1101/ gad.237149.113.

Viswanathan SR, Powers JT, Einhorn W, Hoshida Y, Ng TL, Toffanin S, O'Sullivan M, Lu J, Phillips LA, Lockhart VL, et al. 2009. Lin28 promotes transformation and is associated with advanced human malignancies. Nat Genet 41: 843-848.

Wu MK, Sabbaghian N, Xu B, Addidou-Kalucki S, Bernard C, Zou D, Reeve AE, Eccles MR, Cole C, Choong CS, et al. 2013. Biallelic DICER1 mutations occur in Wilms tumours. I Pathol 230: 154-164.

Yang X, Lin X, Zhong X, Kaur S, Li N, Liang S, Lassus H, Wang L, Katsaros D, Montone K, et al. 2010. Double-negative feedback loop between reprogramming factor LIN28 and microRNA let-7 regulates aldehyde dehydrogenase 1-positive cancer stem cells. Cancer Res 70: 9463-9472. 


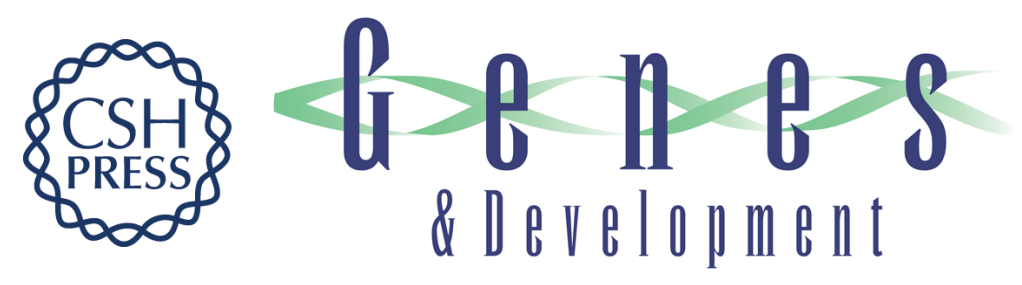

\section{LINking microRNAs, kidney development, and Wilms tumors}

Peter Hohenstein and Nicholas D. Hastie

Genes Dev. 2014, 28:

Access the most recent version at doi:10.1101/gad.242735.114

Related Content Lin28 sustains early renal progenitors and induces Wilms tumor

Achia Urbach, Alena Yermalovich, Jin Zhang, et al.

Genes Dev. May, 2014 28: 971-982

References This article cites 13 articles, 2 of which can be accessed free at:

http://genesdev.cshlp.org/content/28/9/923.full.html\#ref-list-1

Articles cited in:

http://genesdev.cshlp.org/content/28/9/923.full.html\#related-urls

Creative This article is distributed exclusively by Cold Spring Harbor Laboratory Press for the first

Commons

License

six months after the full-issue publication date (see

http://genesdev.cshlp.org/site/misc/terms.xhtml). After six months, it is available under a Creative Commons License (Attribution-NonCommercial 4.0 International), as described at http://creativecommons.org/licenses/by-nc/4.0/.

Email Alerting Receive free email alerts when new articles cite this article - sign up in the box at the top Service right corner of the article or click here.

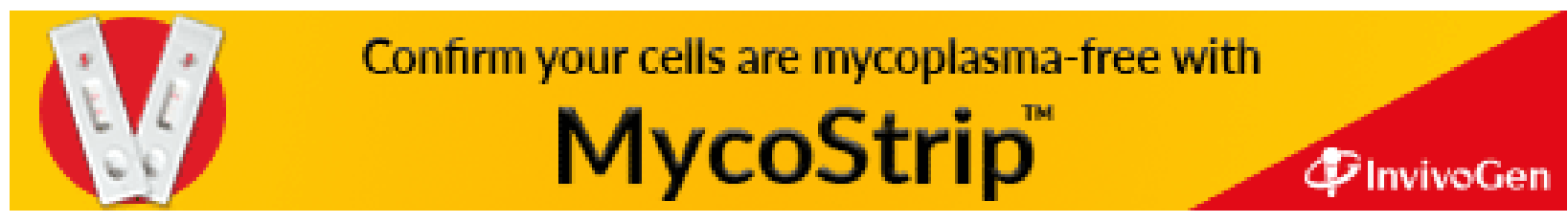

